\title{
Is India Ready to Face "Live with Virus" Phase? A Nationwide Review and a Study on COVID-19 Transmission in Tamil Nadu
}

\section{Aby Paul ${ }^{1 *}$, Joel Joby Joseph ${ }^{1}$, Stelvin Sebastian ${ }^{1}$, Sanjo Saijan ${ }^{1}$, Jeeva Joseph $^{1}$ and Jobin Kunjumon Vilapurathu ${ }^{2}$}

${ }^{1}$ Pharm D Intern, Nirmala College of Pharmacy, Muvattupuzha, Ernakulam, Kerala, India

${ }^{2}$ M Pharm, Associate Professor, Department of Pharmacy Practice, Nirmala College of Pharmacy, Muvattupuzha, Ernakulam, Kerala, India

*Corresponding Author: Aby Paul, Pharm D Intern, Nirmala College of Pharmacy, Muvattupuzha, Ernakulam, Kerala, India.

DOI: $10.31080 /$ ASPS.2020.04.0567
Received: July 06, 2020

Published: July 28, 2020

(C) All rights are reserved by Aby Paul., et al.

\begin{abstract}
2019 Novel Corona Virus (COVID-19) has terrified the world and a community lockdown was the early measure that can be done to prevent the spread of COVID-19 in the countries. We did a nationwide comparison by considering the data from three time intervals of lockdown in the India (March 24th, April 14th and May 3rd of 2020). Kerala's COVID-19 status has improved in the subsequent phases of lockdown. The state reported only 3.36\% and $1.16 \%$ to the total cumulative cases of the nation in the subsequent lockdown phases. The decreased Test: Case ratio of Maharashtra in the subsequent phases of lockdown indicates the thread of community spread in the state or inadequate number of test performed. The impact of population density in spread of COVID19 in the Tamil Nadu was assessed and districts with high population density had higher incidence of cases. The number of fresh cases reported in the State from April 1 to April 15, 2020 was studied and about 100\%-67\% of total new cases reported on these days were associated with the socio-cultural event. The cumulative cases reported in the state had crossed the median forecasted cumulative case by April 20, 2020.The cumulative cases in Tamil Nadu is approaching the upper confidence limit which is a result of a community spread in the state. We conclude that only with the achievement of decreased number and diameter of COVID19 hot spots along with measures to implement social distancing, India would be ready face the "live with virus" phase.
\end{abstract}

Keywords: COVID-19; India; Tamil Nadu; Lock Down

\section{Introduction}

2019 Novel Corona Virus (COVID-19) is a pandemic that has terrified the world since it was reported in China in December of 2019. The reproduction number $\left(\mathrm{R}_{0}\right)$ of Covid-19 infection was found to be in the range of 2-3 all around the world [1]. Social distancing and hygiene measures were recommended to prevent $\mathrm{CO}$ VID-19 transmission. The simulation models of COVID-19's spread and impact on United States proposed that moderate social dis- tancing implemented in late March 2020 could save about 1.7 million lives within seven months [2]. Lockdown was one of the early measures that can be set in place to prevent the spread of COVID-19 in a nation. We already have examples of China, Hong Kong and Singapore which have controlled COVID-19 with strong containment actions nationwide. South Korea also set an example by imparting efficient social distancing and proved that even without lockdown and enhanced by contact tracing we can contain the disease from 
claiming huge mortality rates. It is evident that spread of COVID-19 will cost more lives along with complete socioeconomic disruption World-Wide. Hence there should be effective containment strategies including lockdown and mitigation efforts like hand sanitations to prevent the spread of disease. WHO's Director General also emphasized that "Containment of COVID-19 is feasible and must remain the top priority for all countries "in his press conference on March 2, 2020 [3].

India is the second most populous country in the world and is now fighting the COVID-19 with measures of lockdown. India had index case in the state of Kerala back in January $31^{\text {st }} 2020$. But after that India didn't have any new cases of COVID-19 till early March 2020. In March there were several cases reported in different states of the country. Indian government responded to this pandemic initially by declaring a "Janata Curfew" which lasted for 14 hours on March $22^{\text {nd }} 2020$ [4]. Then India moved on to host a series of lockdown nationwide from March $25^{\text {th }}$ to April $14^{\text {th }}$, April $14^{\text {th }}$ to May $3^{\text {rd }}$ and May $3^{\text {rd }}$ to May $17^{\text {th }}$ [5]. These early interventions in the nation were expected to "flatten the curve" in the country which houses about 1.3 billion people [6]. Indian states response was also exceptional in dealing this pandemic. Kerala, a state in the southern tip of India used contact tracing, community surveillance and experience gained from the effective containment of Niphah virus in 2018 aided to maintain low disease transmission rate in the state. Maharashtra used digitalised technologies including drone surveillance to monitor and assure that there was effective social distance maintained in the densely populated regions of the state, like wise all the states of the nation with its diversities implemented efforts to contain the pandemic [7]. World is moving to a next phase were the economic burden due to the lockdown which freezed the entire economy of the countries had to be moved. Thus the lockdown that is in place would be waived and there will be more mobilization. Lockdown is considered as a bridging period to make medical facilities and other strategies to be in place to deal with the pandemic. In the current knowledge the impact of lockdown in India is not studied in to a good extent. In this article we discuss overall all performance of India during three phases of lockdown and with special reference of Tamil Nadu based on its population density and impact of socio-cultural event in the state.

\section{Methodology}

We conducted a data based observational study. The procedure indicated by the Standards for the Reporting of Observation Studies in Epidemiology (STROBE). We collected the data from different authorised data bases.
The nationwide comparison was prepared by considering the data from three time intervals March $24^{\text {th }}$, April $14^{\text {th }}$ and May $3^{\text {rd }}$ of 2020. We divided the time line of COVID19 in India as three phases Phase 1 (Till March 24 $4^{\text {th }}$, Phase 2(March $25^{\text {th }}$ - April $14^{\text {th }}$ ) and Phase 3 (April $14^{\text {th }}$ - May $3^{\text {rd }}$ ) We collected the data of cumulative cases, Active cases, recovery rate, case fatality rate, test performed in these three time intervals were analyzed. Case: Test proportion was also assessed to analyse the preparedness and testing strategies of the nation as well as individual states data. We used the data of top states which contributed to cases in India in the first phase (March $\left.24^{\text {th }}\right)$. Some of the official data sources used include, https://www. mohfw.gov.in/, https://icmr.nic.in/node/39071, https://twitter. com/PTI_News, https://twitter.com/ANI, https://twitter.com/ the_hindu, https://twitter.com/thenewsminute, http://gis.ndma. gov.in/arcgis/apps/sites/\#/data, https://covid.icmr.org.in/index. php.

The study of Tamil Nadu was carried out after collection of cumulative cases on daily basis. We studied on the population density of different districts and its impact on cumulative cases. We also performed focussed study on the clusters associated with a sociocultural gathering. In order to analyse the impact of lockdown in mitigation of COVID19, we used the forecasting method. We forecasted the possible cumulative cases till May $3^{\text {rd }}$. The data of cumulative cases till April $8^{\text {th }}$ was used to conduct the forecast. The data period of April $8^{\text {th }}$ was selected based on the assumption that the cases reported till 14 days after the declaration of lockdown would have been acquired before lockdown. Data of Tamil Nadu was collected from the media bulletin of Tamil Nadu state government (stopcorona.tn.gov.in).

\section{Statistical analysis}

All data were analyzed using SPSS software (version 18.0; SPSS Inc., Chicago, IL). Numerical variables were represented in numerical and in percentage. We used Autoregressive integrated moving average (ARIMA) $(1,1,3)(0,0,0)$ model to perform the forecast. The upper class limit (UCL) and lower class limit (LCL) were assessed with a confidence interval of $95 \%$.

\section{Results}

We analysed the performance of the Country/State/Union territory in terms of COVID-19 infections during the lockdown (Table 1).

However, to analyse the performance of the states of India during the lockdown phase we selected the top states that contributed the total COVID19 cases reported in the country (Table 2, Figure 1). 
Is India Ready to Face “Live with Virus” Phase? A Nationwide Review and a Study on COVID-19 Transmission in Tamil Nadu

\begin{tabular}{|c|c|c|c|}
\hline Country/State/Union territory & $\begin{array}{c}\text { Cumulative cases on } \\
\text { March } 24^{\text {th }}(\%)\end{array}$ & $\begin{array}{l}\text { Cumulative cases on April } \\
\qquad 14^{\text {th }}(\%)\end{array}$ & $\begin{array}{l}\text { Cumulative cases on May } \\
\qquad 3^{\text {rd }}(\%)\end{array}$ \\
\hline India & 571 & 11485 & 42778 \\
\hline Maharashtra & $107(18.73 \%)$ & $2680(23.33 \%)$ & $12974(30.32 \%)$ \\
\hline Gujarat & $34(5.95 \%)$ & $650(5.65 \%)$ & $5428(12.68 \%)$ \\
\hline Tamil Nadu & $18(3.15 \%)$ & $1204(10.48 \%)$ & $3023(7.06 \%)$ \\
\hline Delhi & $30(5.25 \%)$ & $1561(13.59 \%)$ & $4549(10.63 \%)$ \\
\hline Rajasthan & $32(5.60 \%)$ & $1005(8.75 \%)$ & $2886(6.74 \%)$ \\
\hline Madhya Pradesh & $7(1.22 \%)$ & $741(6.45 \%)$ & $2837(6.63 \%)$ \\
\hline Uttar Pradesh & $35(6.12 \%)$ & $660(5.74 \%)$ & $2645(6.18 \%)$ \\
\hline West Bengal & $9(1.57 \%)$ & $190(1.65 \%)$ & $1198(2.80 \%)$ \\
\hline Andhra Pradesh & $8(1.40 \%)$ & $484(4.21 \%)$ & $1583(3.70 \%)$ \\
\hline Punjab & $29(5.07 \%)$ & $184(1.60 \%)$ & $1102(2.57 \%)$ \\
\hline Telangana & $37(6.47 \%)$ & $644(5.60 \%)$ & $1082(2.52 \%)$ \\
\hline Karnataka & $41(7.18 \%)$ & $260(2.26 \%)$ & $614(1.43 \%)$ \\
\hline Jammu and Kashmir & $6(1.05 \%)$ & $278(2.42 \%)$ & $701(1.63 \%)$ \\
\hline Bihar & $3(0.52 \%)$ & $66(0.57 \%)$ & $517(1.20 \%)$ \\
\hline Haryana & $30(5.25 \%)$ & $198(1.72 \%)$ & $442(1.03 \%)$ \\
\hline Odisha & $2(0.35 \%)$ & $60(0.52 \%)$ & $162(0.37 \%)$ \\
\hline Kerala & $109(19.08 \%)$ & $387(3.36 \%)$ & $500(1.16 \%)$ \\
\hline Chandigarh & $7(1.22 \%)$ & $21(0.18 \%)$ & $97(0.22 \%)$ \\
\hline Jharkhand & 0 & $27(0.23 \%)$ & $115(0.26 \%)$ \\
\hline Tripura & 0 & $2(0.01 \%)$ & $16(0.03 \%)$ \\
\hline Uttarakhand & $4(0.70 \%)$ & $37(0.32 \%)$ & $60(0.14 \%)$ \\
\hline Himachal Pradesh & $3(0.52 \%)$ & $33(0.28 \%)$ & $40(0.09 \%)$ \\
\hline Assam & 0 & $33(0.28 \%)$ & $43(0.10 \%)$ \\
\hline Ladakh & $13(2.27 \%)$ & $17(0.14 \%)$ & $42(0.09 \%)$ \\
\hline Andaman and Nicobar Islands & 0 & $11(0.09 \%)$ & $33(0.07 \%)$ \\
\hline Meghalaya & 0 & $1(0.008 \%)$ & $12(0.02 \%)$ \\
\hline Puducherry & $1(0.17 \%)$ & $7(0.06 \%)$ & $9(0.02 \%)$ \\
\hline Goa & 0 & $7(0.06 \%)$ & $7(0.01 \%)$ \\
\hline Manipur & $1(0.17 \%)$ & $2(0.01 \%)$ & $2(0.004 \%)$ \\
\hline Mizoram & 0 & $1(0.008 \%)$ & $1(0.002 \%)$ \\
\hline Arunachal Pradesh & 0 & $1(0.008 \%)$ & $1(0.002 \%)$ \\
\hline Chhattisgarh & $1(0.17 \%)$ & $33(0.28 \%)$ & $57(0.133 \%)$ \\
\hline Dadra and Nagar Haveli & 0 & 0 & 0 \\
\hline Nagaland & 0 & 0 & 0 \\
\hline Daman and Diu & 0 & 0 & 0 \\
\hline Lakshadweep & 0 & 0 & 0 \\
\hline Sikkim & 0 & 0 & 0 \\
\hline
\end{tabular}

Table 1: COVID-19 cases reported in three phases of nationwide lockdown in Country/State/Union territory. 


\begin{tabular}{|c|c|c|c|c|c|c|c|c|c|}
\hline $\begin{array}{l}\text { Country } \\
\text { and } \\
\text { State }\end{array}$ & $\begin{array}{l}\text { Recovery } \\
\text { rate in } \\
\text { phase } 1\end{array}$ & $\begin{array}{l}\text { Recovery } \\
\text { rate in } \\
\text { phase } 2\end{array}$ & $\begin{array}{c}\text { Recovery } \\
\text { rate in } \\
\text { phase } 3\end{array}$ & $\begin{array}{c}\text { Case fatality } \\
\text { rate in } \\
\text { phase } 1\end{array}$ & $\begin{array}{c}\text { Case fatality } \\
\text { rate in } \\
\text { phase } 2\end{array}$ & $\begin{array}{c}\text { Case fatality } \\
\text { rate in } \\
\text { phase } 3\end{array}$ & $\begin{array}{c}\text { Active } \\
\text { case in } \\
\text { phase } 1\end{array}$ & $\begin{array}{c}\text { Active } \\
\text { case in } \\
\text { phase } 2\end{array}$ & $\begin{array}{c}\text { Active } \\
\text { case in } \\
\text { phase } 3\end{array}$ \\
\hline India & $7.00 \%$ & $11.88 \%$ & $30.02 \%$ & $1.75 \%$ & $3.44 \%$ & $3.66 \%$ & $91.24 \%$ & $84.66 \%$ & $74.85 \%$ \\
\hline Kerala & $3.66 \%$ & $54.52 \%$ & $80.20 \%$ & 0 & $0.77 \%$ & $0.8 \%$ & $96.33 \%$ & $44.70 \%$ & $19.00 \%$ \\
\hline Maharashtra & 0 & $9.66 \%$ & $18.99 \%$ & $1.86 \%$ & $6.60 \%$ & $4.48 \%$ & $98.13 \%$ & $83.73 \%$ & $88.59 \%$ \\
\hline Karnataka & $21.95 \%$ & $27.30 \%$ & $47.71 \%$ & $2.43 \%$ & $3.84 \%$ & $4.07 \%$ & $90.24 \%$ & $68.84 \%$ & $48.20 \%$ \\
\hline Telangana & $2.70 \%$ & $17.08 \%$ & $50.36 \%$ & 0 & $2.79 \%$ & $2.68 \%$ & $97.29 \%$ & $80.12 \%$ & $46.95 \%$ \\
\hline Uttar Pradesh & $31.42 \%$ & $7.57 \%$ & $30.32 \%$ & 0 & $1.21 \%$ & $1.89 \%$ & $68.57 \%$ & $91.21 \%$ & $72.36 \%$ \\
\hline Gujarat & 0 & $9.07 \%$ & $22.01 \%$ & $2.94 \%$ & $4.30 \%$ & $5.87 \%$ & $97.05 \%$ & $86.61 \%$ & $79.08 \%$ \\
\hline Rajasthan & $9.37 \%$ & $14.62 \%$ & $49.82 \%$ & 0 & $1.09 \%$ & $2.66 \%$ & $90.62 \%$ & $84.27 \%$ & $53.56 \%$ \\
\hline Delhi & $20 \%$ & $1.98 \%$ & $31.45 \%$ & $3.33 \%$ & $1.92 \%$ & $1.40 \%$ & $76.66 \%$ & $96.09 \%$ & $74.80 \%$ \\
\hline Haryana & $36.66 \%$ & $27.27 \%$ & $55.20 \%$ & 0 & $1.51 \%$ & $1.13 \%$ & $63.33 \%$ & $71.21 \%$ & $43.66 \%$ \\
\hline Punjab & 0 & $14.67 \%$ & $10.61 \%$ & $3.44 \%$ & $7.06 \%$ & $1.90 \%$ & $96.55 \%$ & $78.26 \%$ & $87.47 \%$ \\
\hline Tamil Nadu & $5.55 \%$ & $6.72 \%$ & $46.60 \%$ & $5.55 \%$ & $0.99 \%$ & $1.02 \%$ & $88.88 \%$ & $92.27 \%$ & $69.79 \%$ \\
\hline
\end{tabular}

Table 2: Recovery rate, Death rate and percentage of COVID-19 cases in India and selected states in lockdown.

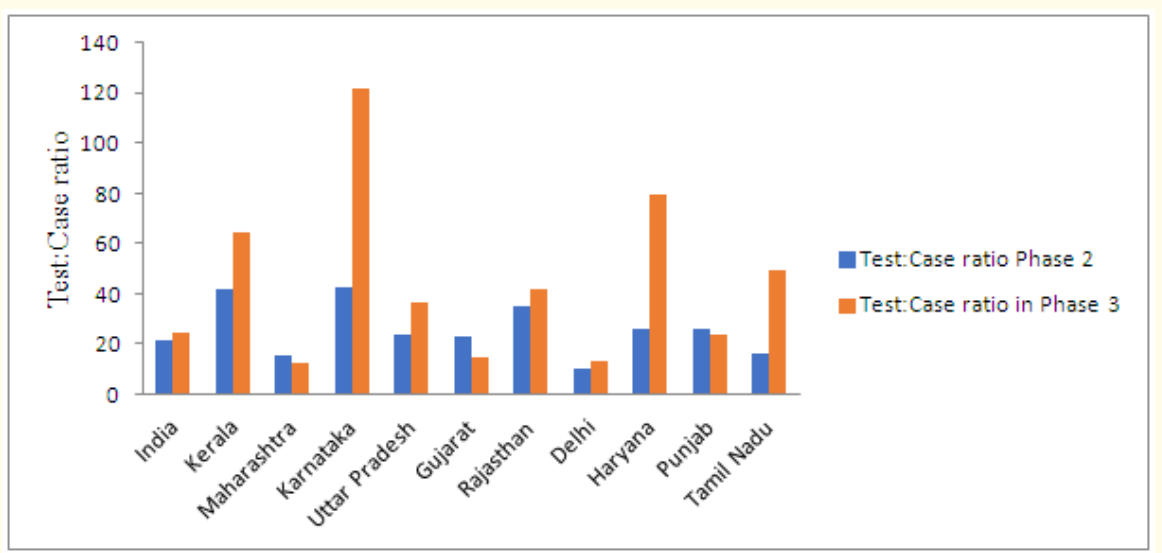

Figure 1: The Test: Case ratio was assessed in Phase 2(on April 14th) and in Phase 3 (on May 3rd) of India and selected states. Country/state (Phase 2: Phase 3): India (21.32:24.46), Kerala (41.95:64.43), Maharashtra (14.32:12.31), Karnataka (42.71:121.98), Uttar Pradesh (24.11:36.23), Gujarat (23.04:14.74), Rajasthan (34.75:41.66), Delhi (10.43:13.24), Haryana (26.31:79.81), Punjab (26.32:23.99), Tamil Nadu (15.99:49.65).

\section{Analysis of Tamil Nadu state}

Tamil Nadu had its index case on March $7^{\text {th }} 2020$ and had everything under control for some time. The cases in Tamil Nadu had raise was associated with a socio cultural event in the country. This led to the exponential rise of cases in Tamil Nadu also. The cases reported in the state with association of the socio cultural event was considered as a cluster of cases.
We categorized 37 districts in the state based on their population density. They were classified as to mildly populated (population density: 100-500/sq.cm), moderately populated (population density: 500-750/sq.cm), and highly populated (population density: $750</$ sq.cm). Based on this, there was 20 districts in mildly populated districts, which included The Nilgiris, Sivaganga, Perambalur, Ramanathapuram, Dharmapuri, Pudukottai, Dindigul, Karur, 
Krishnagiri, Thoothukudi, Ariyalur, Erode, Tiruvannamalai, Theni, Virudhunagar, Tirunelveli, Tiruppur, Kallakurichi, Tenkasi and Villupuram. 11 districts were classified as moderately populated districts, which included were Namakkal, Ranipet, Tiruvarur, Tiruchirappalli, Tirupattur, Nagapattinam, Vellore, Salem, Cuddalore, Thanjavur and Coimbatore. In the classification of highly populated districts we have about 6 districts which incorporated Madurai, Kancheepuram, Tiruvallur, Kanniyakumari, Chengalpattu, Chennai (Figure 2).
On $29^{\text {th }}$ march 2020, when Tamil Nadu had reported 50 cases, Districts with mild population density had 13 cumulative cases where as Districts with moderate population density had $14 \mathrm{cu}-$ mulative cases and Districts with high population density had 23 cumulative cases. On $30^{\text {th }}$ April we had 652, 522, and 1139 cumulative cases in Districts with mild, moderate, high population density and in Tamil Nadu respectively (Figure 3).

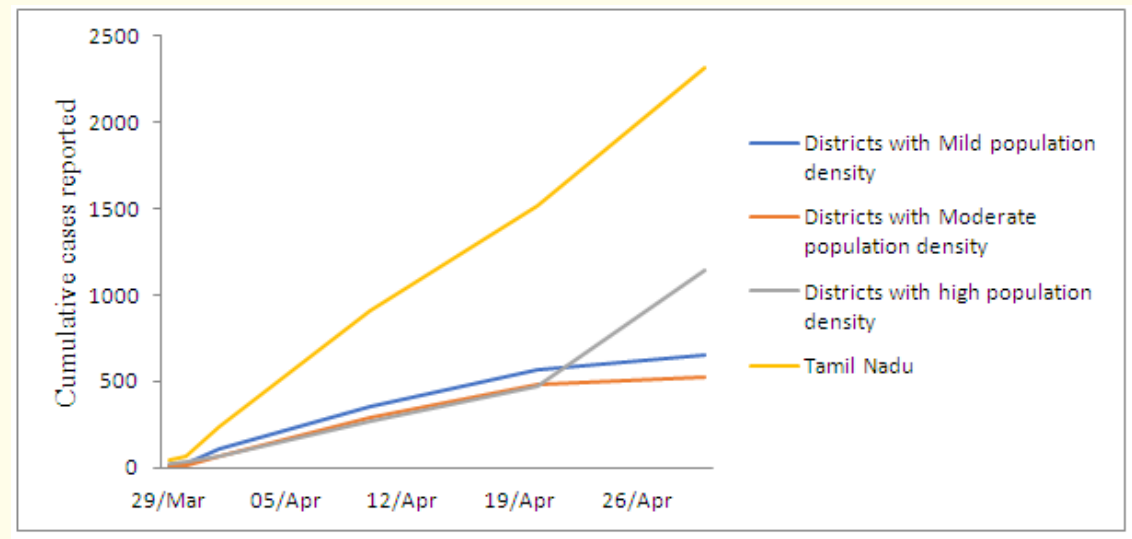

Figure 2: Cumulative cases reported in Districts with mild, moderate, high population and cumulative cases in Tamil Nadu.

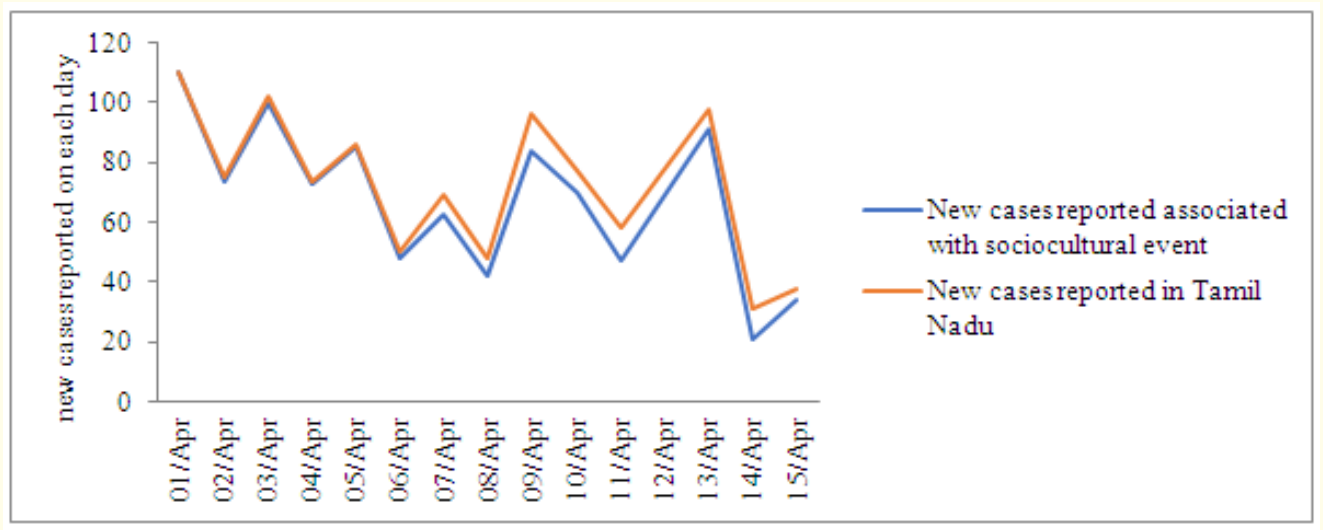

Figure 3: Comparison of new cases reported associated with socio cultural event and in Tamil Nadu. 
We used ARIMA $(1,1,3)(0,0,0)$ model with an moving average method to perform the forecast. The upper confidence limit (UCL) and lower confidence limit (LCL) were assessed with a confidence interval of $95 \%$. The r squared value of this model was 0.718 (Figure 4).

The cumulative cases on May $3^{\text {rd }}$ was 3023 whereas the forecasted cumulative case and UCL cases were 2018 and 3495 respec- tively. This shows that the cumulative case have been $49.80 \%$ more than the forecasted cumulative case and it reached $86.49 \%$ of the UCL cases predicted by May $3^{\text {rd }}$. This shows that the cumulative cases reported in the Tamil Nadu had crossed the median forecasted cumulative case by April 20, 2020.The cumulative cases in Tamil Nadu is approaching the upper confidence limit which is a result of a rapid spread in the state.

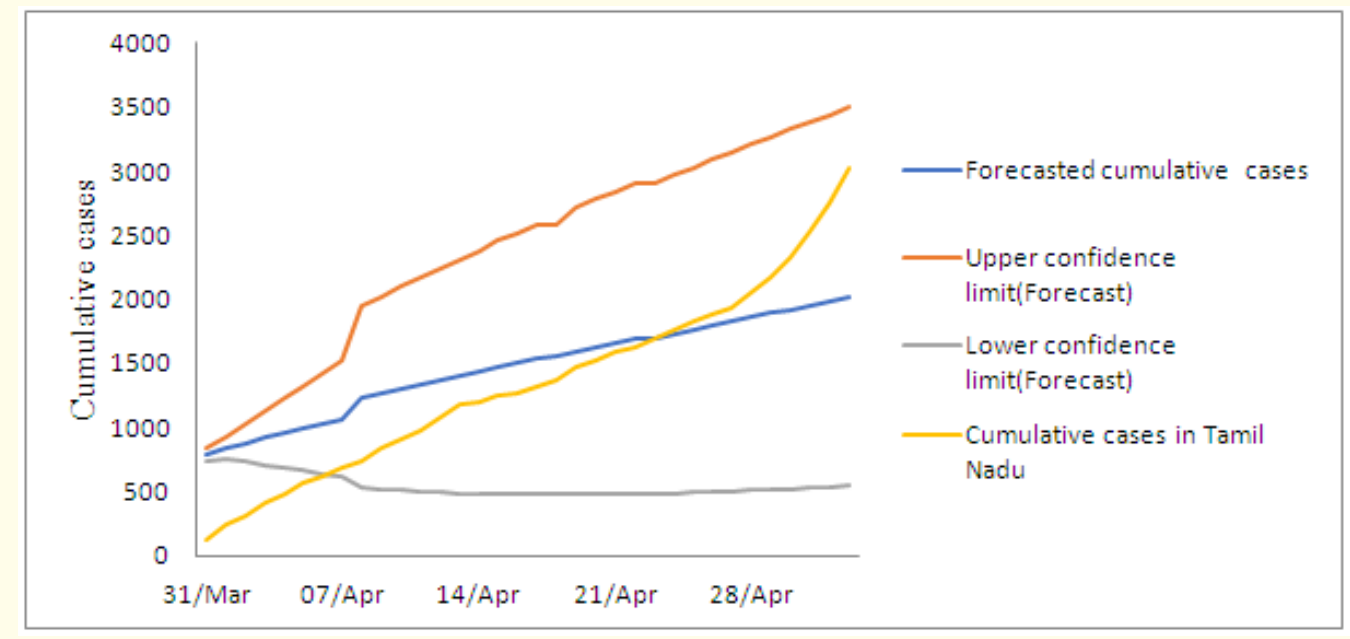

Figure 4: The comparison of ARIMA $(1,1,3)(0,0,0)$ model of forecasting with Cumulative cases in Tamil Nadu.

\section{Discussion}

India could evidently control the infection rate of COVID19 with the early implementation of lockdown in the nation. Kerala has showed a great model for the entire nation. The state was leading in the number of cumulative cases, contributing to $19.08 \%$ of overall cases reported in the entire nation at the time of declaration of first phase of lockdown. Kerala's statistics improved in the subsequent phases of lockdown. The state reported only $3.36 \%$ and $1.16 \%$ to the cumulative cases of the nation in the subsequent lockdown phases (Table 1). Kerala's recovery rate, death rate and percentage of active cases where best in the nation (Table 2). The health department of the state was the first to respond immediately after reporting the three imported cases from China in last week of January. Most of the cases reported in the state were imported cases from Middle East and other western countries. The success mantra was to quarantine all the individuals who came from the COVID19 affected areas. This controlled the spread of COVID19 to a greater extent in the state [8]. Maharashtra was one of the most effected states in nation. Maharashtra continued to report the most cases in the nation in all intervals of the lockdown Phases. It accounted about $18.73 \%, 23.33 \%$, and $30.32 \%$ in the cumulative cases reported in the nation in Phase 1, Phase 2 and Phase 3 respectively (Table 1). The recovery rates, death rates and percentage of active cases reported also didn't show a significant improvement in the lock down phases (Table 2). This clearly describes negative effect of the increasing number of COVID19 cases in the standards of rendering treatment. The test: case proportion of Maharashtra proves that the number of test performed in the community to identify one positive case of COVID19 in the community has decreased from 14.32 in phase 2 to 12.31 in phase 3 (Figure 1). The decreased Test: Case ratio in the subsequent phases of lockdown indicates the thread of community spread in the state or inadequate number of 
test performed. But both these facts points to the need of additional interventions in the state rather than the lockdown to prevent the spread of COVID19 in the state.

Tamil Nadu was one of state in India which reported to control the spread of disease in the state even after being a state which reported huge cluster of cases associated with a socio-cultural event happened in the nation. The state reported to contribute $3.15 \%$ of cumulative cases in nation at the time of declaration of lockdown on March $24^{\text {th }} 2020$. In the Phase 2 of lockdown the state progressed to contribute $10.48 \%$ of cumulative cases reported in the nation. The state managed to reduce its portion to $7.06 \%$ in cumulative cases reported in the nation during Phase 3 (Table 1). But despite the high portions of cumulative case state managed to maintain good statistics in rendering treatment based on recovery rate, death rate and percentage of active cases (Table 2).The Test: Case ratio has improved 15.99 in Phase 2 to 49.65 in Phase 3 (Figure 1). The main reason behind the improvement in the number of test was due to the increase in the number of laboratory facilities for COVID19 testing from nine to forty seven in the end of the Phase 3.The state achieved this number of testing facilities by incorporating the private laboratory facilities along with the limited facilities of the state government. This model can be adopted by other states of nation to improve its testing numbers. The impact of population density in spread of COVID19 in the state was assessed district wise. On $29^{\text {th }}$ march 2020 Districts with mild population density had 13 cumulative cases where as Districts with mild moderate population density had 14 cumulative cases, Districts with high population density had 23 cumulative cases, there were 50 cases reported in Tamil Nadu on this day. On $30^{\text {th }}$ April we had 652, 522, and 1139 cumulative cases in Districts with mild, moderate, high population density and in Tamil Nadu respectively (Figure 2). The results imply that the highly populous districts have to be managed in a different perspective. A case reported from these regions has to be followed by vigorous community testing in that region or else a community spread in these regions would have the potential to saturate the health care facilities. The state also suffered the impact of COVID19 cases associated with a socio cultural event in the nation. The number of fresh cases reported in the State from April 1 to April 15, 2020 was studied and about $100 \%-67 \%$ of cases reported on these days were associated with the socio-cultural event (Figure 3). This depicts the additional burden of COVID19 cases, that a social gathering make. In order to assess the efficiency of the lockdown in the state we forecasted the possible number of cumulative cases from April $1^{\text {st }} 2020$-May $3^{\text {rd }}$ with the data of cumulative cases from March 7,2020-April 8,2020(Figure 4). ARIMA (1,1,3) $(0,0,0)$ model is used to forecast the trends. The trends show that the cumulative cases in Tamil Nadu had crossed the forecasted median number of cumulative cases and are moving along the trend of upper confidence limits of forecast. This result clearly indicates that the lockdown in the state haven't been efficient enough to control or flatten the curve of the pandemic.

The efficiency of lockdown will be questioned regarding the facts of raising cases almost in all top 10 contributing states in terms of COVID-19 numbers of the nation even after the long lockdown, The concerns regarding the spread of COVID-19 to the rural parts of India with the migrating labourers who was moving to their home places because of the unemployment due to the COVID-19 economic crises.

Our study proved that the lockdown was not effective in flattening curves in some states. The spread of COVID19 would be more in regions with high population density and social gatherings would also do harm in prevention of COVID19. India has been in phases of lockdown to prevent COVID19 in past month. But with the raising pressure on the government to wave the lockdown to keep the economy alive will ultimately lead to a scenario of "live with virus" phase. But India need great planning in order to move to this phase.

Lock down could only be waived if; India could reduce the number of COVID19 hot spots in the country. The hot spots should be in complete home quarantine for 7 days and entire population had to be screened for COVID19 after $7^{\text {th }}$ day and home quarantine had to be continued for 14 days before setting these hot spots free. The strategy should be "quarantine, test, quarantine and test". The migrant labourers within and outside the country had to be quarantined in similar way. The diameter of hot spots should also be decreased from state to district, district to panchayth and panchayath to wards. Lock down is a bridging time to achieve this goal [9-11] Meanwhile keen interest has to be placed in implementing administrative level plans that implement more healthcare facilities to meet the challenges of COVID19. Government also has to considered that more cash flow has to be made available in the local markets to boost the Indian economy for the well being of its Citizens.

\section{Conclusion}

From this study we conclude that only with the achievement of decreased number and diameter of COVID19 hot spots along with

Citation: Aby Paul., et al. "Is India Ready to Face "Live with Virus" Phase? A Nationwide Review and a Study on COVID-19 Transmission in Tamil Nadu". Acta Scientific Pharmaceutical Sciences 4.8 (2020): 55-62. 
measures to implement social distancing, India would be ready face the "live with virus" phase. The implementation of lockdown did not have an impact in reducing the transmission of the infection in view of the migrants being increasingly tested positive and the spread of infection from unidentifiable sources. Hence appropriate containment and mitigation strategies and health policies have to be developed and adopted based on the extend of the pandemic level at each places.

\section{Author's Contribution}

- $\quad$ Aby Paul, Joel Joby, Stelvin Sebastian, Sanjo Saijan, Jeeva Joseph were involved in the data collection.

- Aby Paul, Joel joby were involved in statistical analysis and manuscript preparation.

- Jobin Kunjumon Vilapurathu guided and mentored the project and corrected the manuscript

\section{Declaration of Interest}

The authors declare that they have no known competing financial interests or personal relationships that could have appeared to influence the work reported in this paper.

\section{Funding}

No funding.

\section{Ethical Statement}

We have conducted this study in compliance with the all the international ethical standards.

\section{Bibliography}

1. Ying Liu., et al. "The reproductive number of COVID-19 is higher compared to SARS coronavirus". Journal of Travel Medicine 27.2 (2020): taaa021.

2. Greenstone Michael and Nigam Vishan. "Does Social Distancing Matter?" (March 30, 2020). University of Chicago, Becker Friedman Institute for Economics Working Paper No. 2020-26 (2020).

3. WHO Report of the WHO-China Joint Mission on Coronavirus Disease 2019 (COVID-19).

4. The Economic Times (2020).

5. BBC India's 1.3bn population told to stay at home (2020).

6. COVID-19. (2020).
7. The Lancet. "India under COVID-19 lockdown". Lancet (London, England) 395.10233 (2020): 1315.

8. P Maneesh and El Alaoui Aicha. "How Countries of South Mitigate COVID-19: Models of Morocco and Kerala, India”. (2020).

9. A Wilder-Smith and DO Freedman. "Isolation, quarantine, social distancing and community containment: pivotal role for old-style public health measures in the novel coronavirus (2019-nCoV) outbreak". Journal of Travel Medicine (2020): $1-4$.

10. Lewnard JA and Lo NC. "Scientific and ethical basis for socialdistancing interventions against COVID-19". Lancet Infection Disease (2020).

11. Walker PGT., et al. "The global impact of COVID-19 and strategies for mitigation and suppression". Imperial College COVID-19 Response Team (2020).

\section{Assets from publication with us}

- Prompt Acknowledgement after receiving the article

- Thorough Double blinded peer review

- Rapid Publication

- Issue of Publication Certificate

- High visibility of your Published work

Website: www.actascientific.com/

Submit Article: www.actascientific.com/submission.php Email us: editor@actascientific.com

Contact uS: +919182824667 